\title{
粉体におよぼす爆轟衝擊波の効果
}

\author{
鈴木弘茂*・吉田 浩*・木村康 之** \\ (* 東京工業大学原子炉工学研究所・**防衛大学校機械工学教室)
}

\section{Effects of Detonation Shock Wave on Powder Materials}

\author{
By
}

Hiroshige SUZUKI*, Hiroshi YOSHIDA* and Yasuyuki KIMURA**

(* Research Laboratory of Nuclear Reactor Tokyo Institute of Technology, Tokyo
$* *$ The Defence Academy : Yokosuka-shi, Japan

Preliminary studies were made on the effects of high explosive (tetryl) detonation shock wave on powder materials. By the explosive compaction of mixed powder of metals ( $\mathrm{Ti}, \mathrm{Zr}$, and $\mathrm{Si}$ powders) and colloidal graphite, metal carbides were produced. But under the same condition $\mathrm{ZrO}_{2}$ powder did not react with the colloidal graphite.

Strong sintered body ( $>90 \%$ T.D.) was produced from each powder by the treatment. In case of $\mathrm{ZrO}_{2}$ powder compaction, crushing of grains were observed, and the grain crystals were colored according to the magnitude of the detonation energy.

Measurements of the variation of micro Vickers hardness proved to be just like the case of work hardening.

In such a study, the most important technical problem is how to converge the shock wave most effectively on the specimen, so we tried to estimate the distribution of pressure and temperature in the sample holder, as accurate as possible. [Received Feb. 12, 1969]

\section{1. 緒言}

金属加工法として放電加工, 電磁加工, 爆発加工, 超 音波加工など各種の高エネルギー速度加工法の研究開発 が進められておりいろいるな目的に応用されつつある。

従来爆発加工法は金属の絞り加工, 圧着, 切断, 穿孔 などに用いられていたが, 最近では耐熱材料や超硬材料 の新しい合成あるいは製造方法としても非常に注目され るに至っている.すなわち従来の方法では非常な高温焼 成を必要とする $\mathrm{BeO}, \mathrm{MgO}, \mathrm{Al}_{2} \mathrm{O}_{3}, \mathrm{UO}_{2}$ などの高融点 酸化物粉末やタングステン，タンタル，モリブデンなど の耐熱金属あるいはステンレス鋼，ジルカロイなどの合 金粉末，さらには，サーメットなどの燒結をこの方法 で，特別な加熱操作なしにしかも瞬間的にほとんど理論 密度近くなで進行させることができると報告され，工業 的にも有望視されている文〜5)。また，同様な方法による 金属炭化物の合成も報しららている ${ }^{6)}$. しかし瞬間的な 高圧下におけるこのような過程の機構はまだ十分な説明 が成されて扔らず，実験の難しさとともに多くの問題を 残している.

著者らは，まず高エネルギーの徨撃波がこうした粉末 の高密度化や化学反応に大きな效果をもたらすことを確 かめながら, 各種の要因の相互関係を明らかにするため 征，予備的に高爆薬の爆発に上る粉体の圧控緻密化々炭 化反応とを研究した。爆薬の爆発の際に生ずる衝撃波の
作用機構について二，三の知見を得るとともに，従来必 ずしもよくわかっていなかった爆䡛装置内の圧力や温度 の分布を観察し，この種の方法による高融点物質粉末の 緻密化に対するそれらの影響を論じた。

\section{2. 実験}

\section{1 実験装置之粉末原料}

著者らの用いた装置は，図-1 に示寸ように軟鋼製試 料円筒と爆薬を支持する塩化ビニル管，木製のキャップ および栓, 六号電気雷管などから構成されており，上端 から下方へ爆霸波が伝播する.

この装置は著者の一人，木村が作製したものの一つで

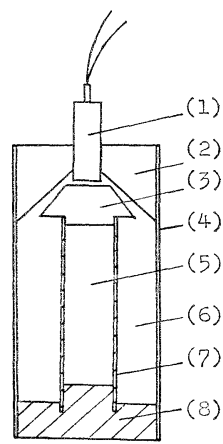
(1) : electric detonator
(2) : wooden cap
(3): wooden cone
(4) : vinyl cloride tube
(5) : powder material
(6) : powder explosive
(7): steel tube
(8): steel base

Fig. 1. Assembly with explosive change and cap in place. 
あり，実験目的に志じていろいろな改良も行なってい る.

試料粉末は図のように円筒内に詰められるが，その 䟢，試料の上下部に脱脂綿を詰めて圧搾時に系内のガス 㺼試料外に逃がすようにしておく、爆㰆の際に試料円筒 の破壞を避けるために円筒の周囲に充填する爆薬は，円

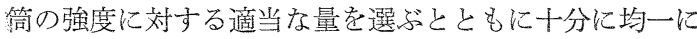
する必要がある。

装置の樍造上，下端部分は反射衝㢣波などの作用によ り破壞され易いが、それだけ他の部分より高い压力を受 けると考えられる，使用した爆薬は，純粋な微粉状テト リルで，爆轟圧力の調節はテトリルの充填量すなわら充 填密度を変えることで可能で要る7)。しかし著者らの用 いた装置では，爆䕎波の圧力と試料中に生ずる実際の圧 力を知ることは容易でない，今回の実験ではテトリルの 充填密度は $0.71 \sim 1.10 \mathrm{~g} / \mathrm{cm}^{3}$, 計算される爆霸波圧力は 大体 $20 \sim 120 \mathrm{~kb}$ である ${ }^{8), 9)}$.

爆薬の有する全エネルギーは極めて大きく普通の化学 反応熱の数倍以上に達するものもあり，テトリルもこの ような類に属する高爆薬である。しかし本実験装置の場 合は，爆薬の燃燒熱による効果はそれほど期待できず， 極めて短時間に発生する強大な圧力に特徵づけられるよ

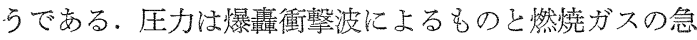
激な膨脹によるものとが考えられるが，今回の実験のよ らに空気中でほとんど解放状態で爆霸させる場合には， 前者による作用の方が大きいものと考えられる ${ }^{10) \sim 16)}$. 本実験の題目もこのような観点に立って用いたものであ

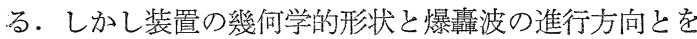
考えると，本実験では，爆轟波の圧力を十分に利用する 垤っていないと考えられる。

一方，実験に供する原料粉末としてチタン，シリコ ン：ジルコニウムの金属粉末と，2種の純度のジルコ ニア粉末（それぞれ通常量のハフニアを含んで，99.5， 99.9\%) と粒状の電融安定化ジルコニアおよびコロイド 状黒鉛を使用した。ただし，チタン粉末は，粒子の表面 が大気中で酸化されて活性を減じることをできるだけ避 汀るために，実験の都度，スポンジ・チタンを水素化し 微粉碎後，これを約 $600^{\circ} \mathrm{C}$ で熱分解して調製したもの である。

チタンと化学的性質の類似するジルコニウムの粉末は 比較のため，上述のような意味での活性なものでなく， 比較的古い，従って，粒子表面が酸化されているとみら れるものを使用した。

各粉末の粒度を以下に示す。

$$
\begin{aligned}
& \text { チ タ V }:<10 \mu \\
& \text { ジルコニア }(99.5 \%):<\text { 数百 } \mu \\
& \text { シ リ コ v }: 400 \# \\
& \text { ジルコニア }(99.9 \%):<10 \mu
\end{aligned}
$$

Table. 1. Experimental condition, packing type and weight of Tetryl.

\begin{tabular}{cccllcc}
\hline No. & Material & $\begin{array}{c}\text { Mole } \\
\text { ratio }\end{array}$ & Packing & $\overbrace{\begin{array}{c}\text { weight } \\
(\mathrm{g})\end{array}}^{\text {Tetryl }}$ & $\begin{array}{c}\text { density } \\
\left(\mathrm{g} / \mathrm{cm}^{3}\right)\end{array}$ \\
\hline 1 & $\mathrm{Ti}+\mathrm{C}$ & $1: 1$ & Pellet & $80(70)$ & 0.86 \\
2 & $\mathrm{Si}+\mathrm{C}$ & $1: 1$ & Powder & $68(58)$ & 0.77 \\
3 & $\mathrm{Zr}+\mathrm{C}$ & $1: 1$ & Pellet & $66(58)$ & 0.71 \\
4 & $\mathrm{Zr}+\mathrm{C}$ & $1: 1$ & Powder & $69(63)$ & 0.77 \\
5 & $\mathrm{Zr}+\mathrm{C}$ & $1: 1$ & Powder & $81(65)$ & 0.80 \\
6 & $\mathrm{ZrO}_{2}+\mathrm{C}$ & $1: 3$ & Powder & $75(65)$ & 0.80 \\
\hline
\end{tabular}

Parentheses indicate Tetryl weights just around steel tubes

$$
\text { ジルコニウム }
$$

電融安定化ジルコニア：26\#〜60\#

コロイド状黒鉛： 40 $\mathrm{mm}$

\section{2 各種金属崖化物の合成实験}

表-1 に示すように，コロイド状黒鉛と各種金属粉末 をそれぞれ配合し，瑪悩乳鉢で十分に混合後，これを粉 末のまま，あいはペレット状にして試料円筒内に充填 した、ペレットは, 圧力 $100 \mathrm{~kg} / \mathrm{cm}^{2}$ で予備成形後, ラ バー・プレスで $3 \mathrm{t} / \mathrm{cm}^{2}$ の圧力をかけて本成形したもの である。次いで，この円筒と塩化ビニル管との間にテト リルをできるたけ均一に充填した。

\section{3 各種金属およびジルコニア粉末の压搾燃結害験}

表-2 に示すように，それぞれの粉末を円筒にタップ 充填後，いろいろな爆薬量で爆宰圧搾（以後圧搾と略記 する)した。

Table 2. Experimental condition, packing type and weight of Tetryl.

\begin{tabular}{cccrc} 
No. & Material & Packing & \multicolumn{2}{c}{ Tetryl } \\
\hline 1 & $\mathrm{Zr}$ & Powder & $80(75)$ & 0.92 \\
2 & $\mathrm{Si}$ & Powder & $83(75)$ & 5.92 \\
3 & $\mathrm{Si}$ & Powder & $105(90)$ & 1.10 \\
4 & $\mathrm{ZrO}_{2}{ }^{*}$ & Powder & $72(60)$ & 0.74 \\
5 & $\mathrm{ZrO}_{2}{ }^{*}$ & Powder & $105(90)$ & 1.10 \\
6 & $\mathrm{ZrO}_{2}{ }^{*}$ & Powder & $83(69)$ & 0.85 \\
7 & $\mathrm{ZrO}_{2}{ }^{*}$ & Powder & $97(84)$ & 1.05 \\
8 & $\mathrm{ZrO}_{2}{ }^{* *}$ & Powder & $99(80)$ & 1.00 \\
9 & $\mathrm{ZrO}_{2}{ }^{* * *}$ & Powder & $97(80)$ & 1.00 \\
\hline
\end{tabular}

Parentheses indicate Tetryl weights just around steel tubes

* powder of Zirconia, purity : $99.9 \%$ (including $\mathrm{HfO}_{2}$ )

** fine powder of Zirconia, purity : $99.5 \%$ (including $\mathrm{HfO}_{2}$ )

*** $(26 *-60 \#)$ grains of fused and stabilized Zirconia

金属粉末ほ炭化物合成実験に供したものと同一原料で ある.ジルコニア粉末湔述の非安定化ジルコニアと電 融安定化ジルコニアを用いた．

\section{3. 実験結果と考察}

\section{1 炭化物の合成}

圧控後, 試料を 図-2 のように (I)〜 (IV) に分けて 取り出し，それぞれの中心部分の塊状になったものを粉 末X線分析した．表-3 にその結果を示すが，表中の空 白部分は圧搾の際試料が飛散したためである．装置の下 


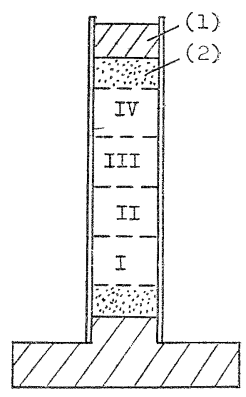

(1): steel plug

(2) : cotton wool

Fig. 2. Sample holder of steel tube.

Table 3. The results of X-ray diffraction analyses of products shown in Table 1.

\begin{tabular}{ccccccc}
\hline \multirow{2}{*}{ No. } & Product & \multicolumn{5}{c}{ Position of sampling in steel tube (Fig. 3) } \\
\cline { 3 - 6 } & & I & II & III & IV \\
\hline 1 & TiC & +++++ & +++++ & & \\
2 & SiC & +++ & - & - & + \\
3 & ZrC & + & - & & \\
4 & $\mathrm{ZrC}$ & ++ & + & + & + \\
5 & $\mathrm{ZrC}$ & +++ & - & - & - \\
6 & ZrC & - & - & - & - \\
\hline+++ : a lot of & +++ : medium & ++ \\
+ & : little a little \\
blank : lack of sample & - : not detected
\end{tabular}

端部 (I) に抒ける各種炭化物生成の例を図-3 に示す.

No. 1 では（a）のように未反応チタンが検出されな いから，この部分では原料チタンはほとんどグラファイ トと反応したことがわかる。

No. 2 では (I) と (IV) で $\beta$-SiC 召生成している が，(b) に示すように未反応シリコンも残存している。

No. 3，4，5 牥それぞれ，テトリル使用量が 66,69 , $81 \mathrm{~g}$ の場合であり，（Ｉ）.の部分に限るならば爆薬量の 多いほぼ，すなわち衝撃波圧力の高いほど炭化反応が起 こり易いと言える、しかしながら最むテトリル量の多い No. 5 でも未反応ジルコニウム金属がかなり残っている ことが(c)から認められ

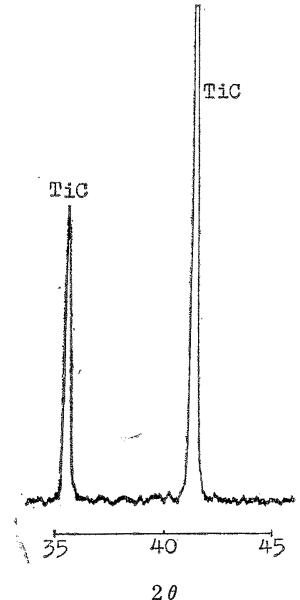

(a) $\mathrm{Ti}+\mathrm{C}=\mathrm{TiC}$ る。

No. 6 では炭化物が全 く認められないので,こ
の混合粉末では反応は起こり難いと言える.この例につ” いては，さらに後述する.

以上の結果から。混合試料は爆䡜による衝撃波のため 何らかの影響を受けて短時間に固相反応を起こすに至る ことがわかった。また，原料の種類や性状による反応の 難易の他任置内の位置による影響も相当大きく, 試料 円筒内の半径方向への位置と共に円筒軸方向一の位置に よっても圧力や温度の受け方にかなりの相違のあること が推察される.この点を詳しく調べることにより, 粉体 中を伝播する衝撃波の挙動をある程度明らかにし，今後 の研究において考慮すべき問題点を浮彫りにできると思 われる、本論文はこのような点に注目しつつ実験し，そ の結果について考察したものである.

ところで結晶子は衝撃波によって圧縮されて外見的な 破砕と共に結晶中に種々の久陥を生し，その結果，粒子 は極为て活性化された状態になると信ぜられる ${ }^{17) ~ 20) . ~}$

また，衝撃波の運動エネルギーの一部は熱エネルギー に変換し，試料の温度を上昇させる。しかし，圧力の持 続時間は，マイク口秒からたかだかミ秒程度であろら から，その間に試料中に発生した熱がどのように伝播 し，その到達する有效温度はどれくらいかといらことは 極めて興味あるが，また難しい問題でもある。

反応が発熱反応である場合には，瞬間的な加熱によっ てもそれが引金となり，衝撃波によってあらかじめ活性 状態にある系は反応を持続し得るといらことは考えられ ぬことではない，放射線損傷の回復に伅ても類似のこ とがみられる ${ }^{17), 18)}$.

な扮，この種の方法では，原料粒子の表面の酸化皮膜 は衝撃波によって瞬間的に粉砕されて金属表面が露出す るから，酸化膜の存在は反応性にあまり影響を与えない と考えられている ${ }^{199}$ が，本実駼結果はそのような従来の 説と必ずしも一致しなかった。すなわち，テトリル量の あまり違わない表-2 中の No. 1 (80 g) と No. 5 (81 g) に扔けるチタンとジルコニウムの反応性の差は,や はり原料粒子の性状, とくに粒子表面の酸化膜の存在に 起因すると考えざるを得ない。すなわち，実験の都度調。

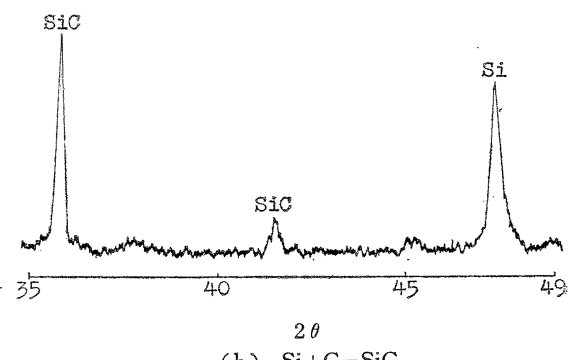

(b) $\mathrm{Si}+\mathrm{C}=\mathrm{SiC}$

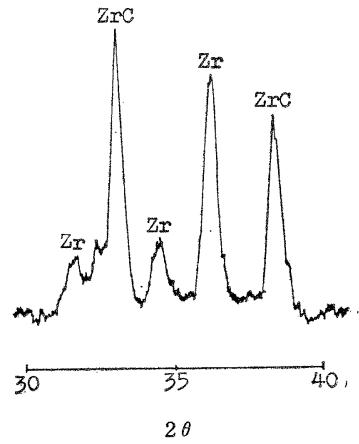

(c) $\mathrm{Zr}+\mathrm{C}=\mathrm{ZrC}$

Fig. 3. X-ray diffraction patterns of products. 
39 鈴木弘笺ほ心

製されたチタン粉末の方が，古いジルコニウム粉末より も炭化反応に対して活性であったと考党られる。

このことからこの方法による固相反応でも原料は， フレッシュかつ微細であることが望ましいと言える。

衝撃波によって系が圧縮されてしまうこの方法では， 生成ガスを伴ら固相反応は当然進行し難く, 今回の実験

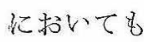

$$
\mathrm{ZrO}_{2}+3 \mathrm{C} \rightarrow \mathrm{ZrC}+2 \mathrm{CO}
$$

の上うな反応は起こらなかった。

このほか，系内に含まれた空気が压些時の炭化反応に ぞのような影響を与えるか，および，㐫らかじめ粒子が

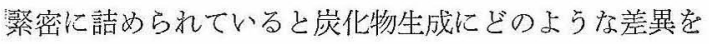
生ずるかをしらべるため No. 1 と No. 3 で混合試料を ペレットにして実験を行なったが，はっきりした差異を 埧めるに至らなかった。

単体の粉末の圧㩁維密化実験では系内の空気の存在に よる差異はほとんど認められないと報告されている11.

\section{2 高融点物質の圧搾による焼結と組織}

表ー2 について得られた試料から幾つか選び，耑密度 と気孔率を測定した（表-4）。

Table 4. Bulk densities and porosities of explosively compacted bodies.

\begin{tabular}{cccccc}
\hline Material & $\begin{array}{c}\text { Grain } \\
\text { size } \\
(\mu)\end{array}$ & $\begin{array}{c}\text { Purity } \\
(\%)\end{array}$ & $\begin{array}{c}\text { Weight } \\
\text { of } \\
\text { Tetryl }(\mathrm{g})\end{array}$ & $\begin{array}{c}\text { Bulk } \\
\text { density } \\
(\%)\end{array}$ & $\begin{array}{c}\text { Apparent } \\
\text { porosity } \\
(\%)\end{array}$ \\
\hline $\mathrm{Zr}$ & $<10$ & 99.6 & $83(75)$ & 91.6 & 5.3 \\
$\mathrm{Si}$ & 400 \$ & 99.999 & $83(75)$ & 79.8 & 15.7 \\
$\mathrm{Si}$ & 400 \# & 99.999 & $105(90)$ & 90.8 & 7.5 \\
$\mathrm{ZrO}_{2}$ & 500 & 99.5 & $105(90)$ & 94.9 & $5.1^{*}$ \\
$\mathrm{ZrO}_{2}$ & $<10$ & 99.5 & $99(80)$ & 98.6 & $1.4^{*}$ \\
$\mathrm{ZrO}_{2}$ & $<10$ & 99.9 & $68(53)$ & 98.4 & $1.6^{*}$ \\
$\mathrm{ZrO}_{2}$ & $26 \$-60 \$$ & Fused & $70(57)$ & 97.0 & $3.0^{*}$ \\
\hline
\end{tabular}

* total porosity

$\mathrm{Zr}$ and $\mathrm{ZrO}_{2}$ including $\mathrm{Hf}$ and $\mathrm{HfO}_{2}$

シリコン粉末, ジルコニウム粉未, 各種のジルコニア 粉末のいずれも適当なテトリル量の使用によって理論密 度に近く, 気孔率も10\%以下の維密なものが得られた。

表から,シリコン粉末の場合。爆楽量の増加は密度の 増加をむたらすこと、ジルコニア粉末の場合，原料粉の 種類, 粒度の違いにもかかわらず高密度を達成し得るこ とがわかる。また，微細なジルコニア粉末ではテテトリ ル $68 \mathrm{~g}$ で密度は $98 \%$ T.D. 以上に達する.

粗い粒子から成る電融ジルニニアも比較的少ない爆薬 量で理論密度近くまで維密化した。

衝撃波の強さの違いによる王㩁状態の差異を詡べるた めに、ジルコニアについては, 種々の爆薬最で実験を掞 こなって, 得られた压竅体の組織它光学拉よび電子顕微 鏡, その他で観察した。

図-4 は，表-2の No. 4 でテトリル $72 \mathrm{~g}$ を用いて 得られたジルコニア压㩁体の中心軸儿垂㨁な断面であ る。中心部には，ほぼ円形の大きな中心孔と，ほぼそれ

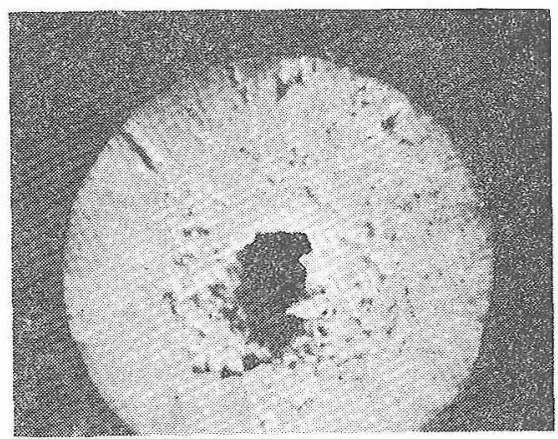

Fig. 4. Cross section of explosively compacted $\mathrm{ZrO}_{2}$, using $72 \mathrm{~g}$ of Tetryl. $(\times 6)$

を囲む多数のクラックが認められるが，その他の部分で はか子りの緻泌化が進んでいる。注意媣く観察すると同 心叮状に区別し得る幾つかの層から成り立っている、中 心孔付近では粒子が多数集まってできた二次粒子が粗に 充填しているが，外縁部では二次粒子が針状あるいは錐 状に発達し，しかもそ彷が維密に充填した組織至し ている。矢の幅は半径方向に約 $1 \mathrm{~mm}$ に達する。

な扔，本実験例で装置内の試料円筒部のテトリルは $60 \mathrm{~g}$ でその爆聶圧力は大体 $20 \mathrm{~kb}$ と見穦られる ${ }^{9}$.

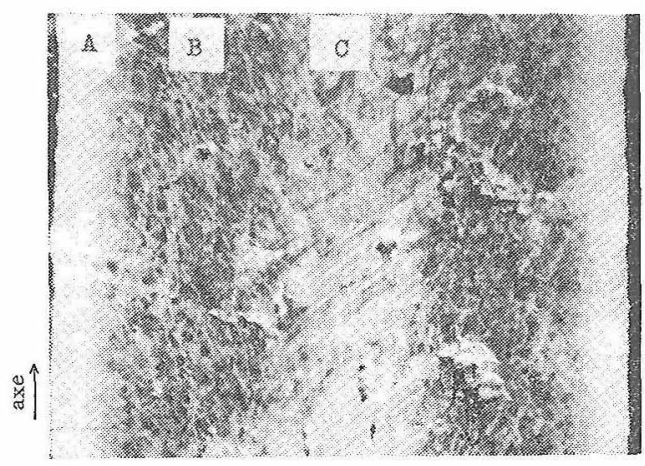

(A) : Outer part, (B) : Middle part, (C) : Central part

Fig. 5. Longitudinal cross section of explosively compacted $\mathrm{ZrO}_{2}$, using $97 \mathrm{~g}$ of Tetryl. $(\times 8.4)$

図-5 注，No. 7 でテトリル $97 \mathrm{~g}$ (円䇠部 $84 \mathrm{~g}$ で圧 力は約 $100 \mathrm{~kb}$ ) を用いて得られた圧售体の中心軸飞沿っ た断面で，中心孔はないが著しく異なった幾つかの領域 加ら成っている，殊に，興味ある点は色相の変化で，約 $1 \mathrm{~mm}$ の幅の外緣部任白色やや半透明であるのに中間部 ほ灰黑色を是し，中心部は再び白色に近くなっているこ とである。装置内の試料冈筒部でのテトリルの充填量拉 よび充填密度の最大である No. $5\left(90 \mathrm{~g}, 1.10 \mathrm{~g} / \mathrm{cm}^{3}\right)$ の場合でむ組織と色相に同榜の傾向が見られた。 その各 部分圭湿微鏡観察した（図-6〜9）.

図-6 法外緣部で，外見的にはそれほど破砾されてい ない，粒形のはっきりした白色粒子とほぼ同数の粒形の 不明膫な灰黑色に見える粒子から成り立っている。 
図-7 は中閒部で，粒子のあるものはかなり細かく破 砕されているが，大多数はほぼ外緣部の粒子と同しくくら いの大きさである、しかし白色の粒子は少なく，不明膫 な灰黒色に見える粒子が主体しなっている。

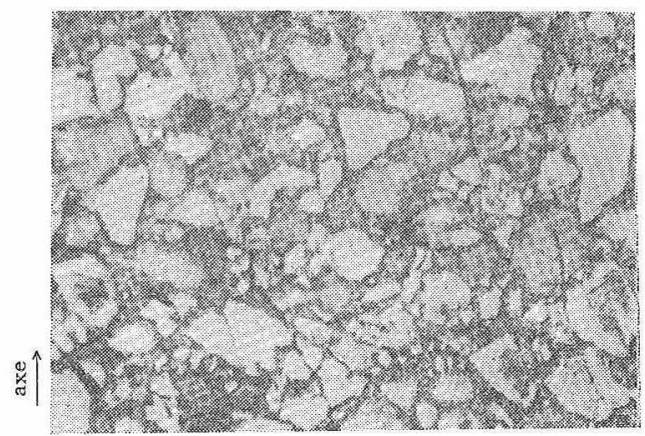

Fig. 6. Outer part of longitudinal cross section of explosively compacted $\mathrm{ZrO}_{2}$, using $105 \mathrm{~g}$ of Tetryl. $(\times 60)$

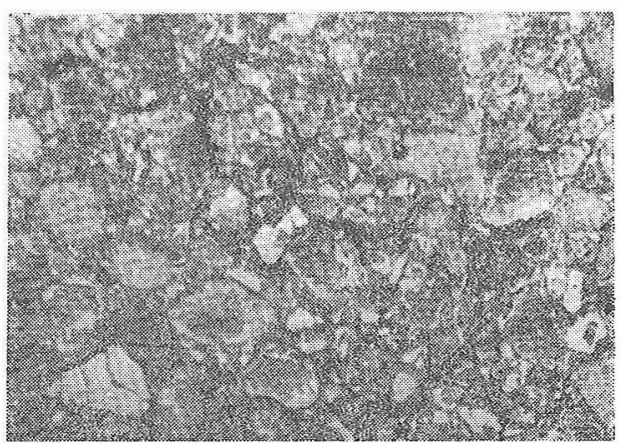

axe

Fig. 7. Middle part of longitudinal cross section of explosively compacted $\mathrm{ZrO}_{2}$, using $105 \mathrm{~g}$ of Tetryl. $(\times 60)$

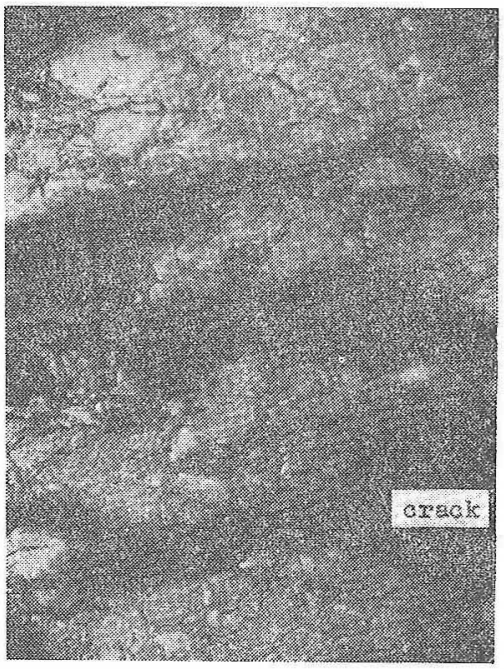

$\stackrel{\text { axe }}{\longrightarrow}$

Fig. 8. Central part of longitudinal cross section of explosively compacted $\mathrm{ZrO}_{2}$, using $105 \mathrm{~g}$ of Tetryl. $(\times 60)$
図-8は中心部で，もとの粒子はほとんど原外形を罍 めておらず，もとの粒界と関係のないクラックが中心蟿 に沿って存在する。この部分をさらに詳しく電子顕微鏡 観察してみる(図-9）と粒子は1 以下になっており， しかもかなり緻密になっているように見えるが，粘子の あるものはまわりの組織との間にすき間を生じ一部は剝 落している。

図-10 は，外縁部の白色に見える粒子の近傍を約 350 倍に拡大したものである. 白色粒子はその表層部が極め て微細化され，しかも全体的にはもとの粒形を留めてい z.

図-11 はここのよな表層を有する白色粒子の周りの

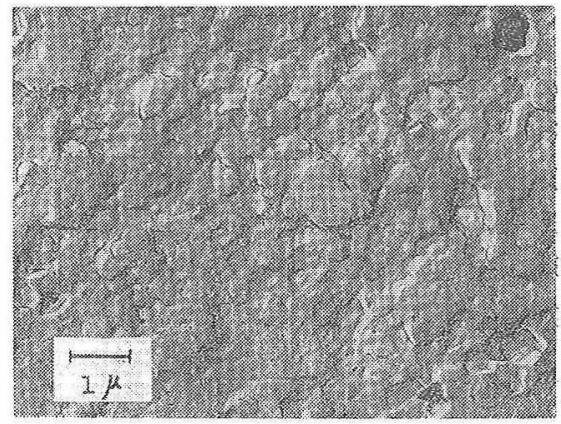

Fig. 9. Electron microphotograph of explosively compacted $\mathrm{ZrO}_{2}$ shown in Fig. 8. $(\times 12500)$

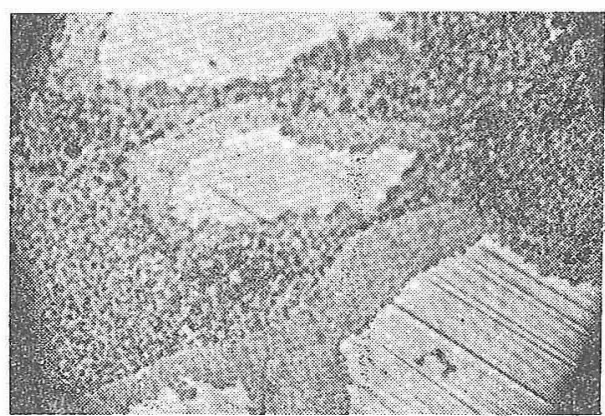

Fig. 10. Typical microstructure of explosively compacted $\mathrm{ZrO}_{2}$ shown in Fig. 6 . $(\times 350)$

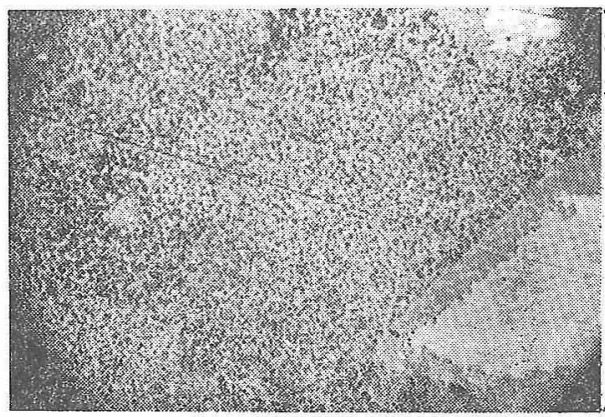

Fig. 11. Typical microstucture of explosively compacted $\mathrm{ZrO}_{2}$ shown in Fig. 6 . $(\times 350)$ 


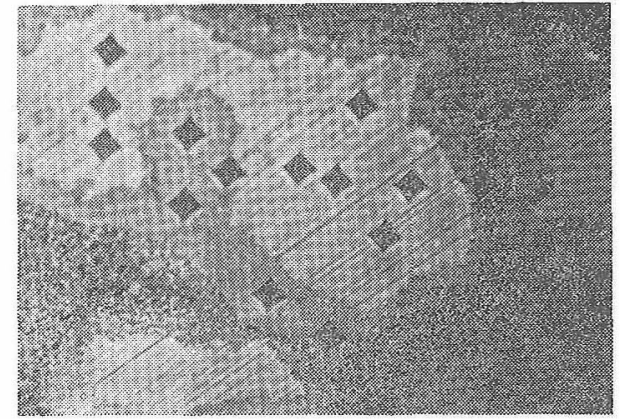

Fig. 12. A part of cross section of explosively compacted $\mathrm{ZrO}_{2}$ shown in Fig. 6 . Each diagonal of indentations is about $13.5 \mu\left(\mathrm{Vhn} \fallingdotseq 1000 \mathrm{~kg} / \mathrm{mm}^{2}\right)$. $(\times 350)$

いわゆる粒形不明橑な扊黑色粒子を約 350 倍に拉大した ものである。もとの粒界付近はややすき間が多くなって いるほかはほとんど粒界消消え，全体的に極めて微細化 している．写真の上部の台色籸子の表層部よりやや粗い が互いに繁密に結合している。

図-12 は，白色粒子とその表層部およびその彫囲の锁 少硬度の差を調心゙るためのピラミッド形ダイヤモンド压 子の压痕定示すが，100 g の荷重では各部分はほとんど 同じ硬さ学示した。

図-13 は，No.7 のテトリル $97 \mathrm{~g}$ 起用いて得をジル コニア圧售体の軸方向に直角に曲げ応力走かけた際, 外 縁部に生じた破断の椂子を圭すもので，破断線が粒界の みでなく粒内も通っていることから，もとの粒子は微細 化された粒子をなかだちとして十分強固に結合されてい ることがわかる。

以上の観察結果から，個々の粒子には破研の程度に差 異があるが，粗い粒子加らなるジルコニア粉末でも適当 量のテトリルを用いれば十分繳密な焼結体となし得る可 能性のあることがわかった。

本実験では，装置の幾何学的形状から鮙敉波は収れん しつつ内部に伝播し圧力効果を高 めるが，爆薬量が少なく試料中の 衝撃波が伝播の過程で減衰してし まう場合に法，压搾体の中心部の 粒子の結合は不十分なものとな る. 表-2の No. 4 がこれに相当 する。逆に衝馨波が過大な時に は，中心で衝突して膨脹波に䎐ず

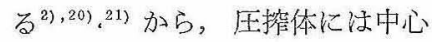
軸に沿ってクラックあるいは中心 孔を尘ずる。

また，衡慗波は試料中を伝播す る過程でエネルギーの一部を試料 および系内のガスの断熱圧縮熱，

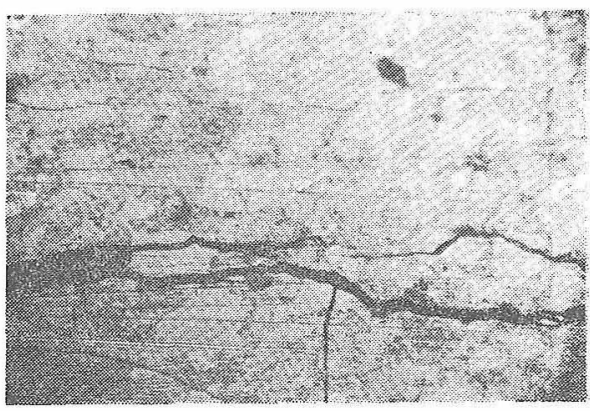

Fig. 13. Fracture path in explosively compacted $\mathrm{ZrO}_{2}$, using $97 \mathrm{~g}$ of Tetryl. $(\times 60)$

粒子間の摩擦熱などに変換して試料を瞬閒的に加熱す る.このような加熱作用も当然中心部の方が大きいこと は炭化区応実験からも裹付けられるが，その有效な到達 温费はどれくらいか不明である。このような压力と温度 がジルコニアの変態にどのような影響を与えるのか圧婃 体の組織にどのよらな変化を与えているかについては後 刻報告したい。

ジルコニア埌搾体にみられた色相変化も，衙揧波によ る極めて瞬閒的な高圧と加熱に直接起因するもので，使 用する爆薬量の多いほど濃い黑色となる。これがどのよ らな種類の色中心であるか，その生成機構と共に現在检

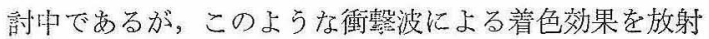
線照射実験で知られている着色效果と共に考えてみるこ と忖極めて興味あるところである。

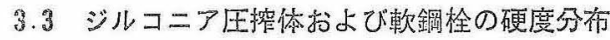

図-14 㳖，表-2 の No. 4 で得られたジルコニア王控 体について半径方向に測定した微小硬度分布である。 图-14 からら尒想されるように，外緣部の硬度は中心に 向って堌加し $0.5 \mathrm{~mm}$ くらいで最大に達した後, ゆる やかに低下する. $1.5 \mathrm{~mm}$ くらいから急激な低下を示し $1.7 \mathrm{~mm}$ 以上では测定できなくなり $1.9 \mathrm{~mm}$ 付近で中心

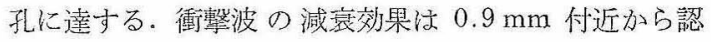
められ，各測定位置での硬度のバラつきが苼しい。この

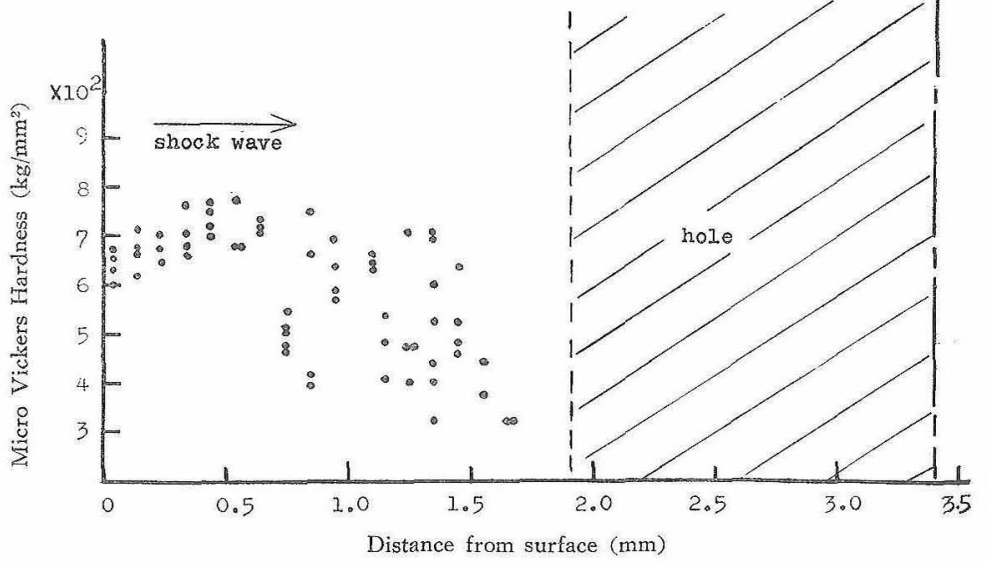

Fig. 14. Micro Vickers hardness distribution of explosively compacted $\mathrm{ZrO}_{2}$, using $72 \mathrm{~g}$ of Tetryl. $\left(\mathrm{ZrO}_{2}+\mathrm{HfO}_{2}=99.5 \%\right.$ in purity) 


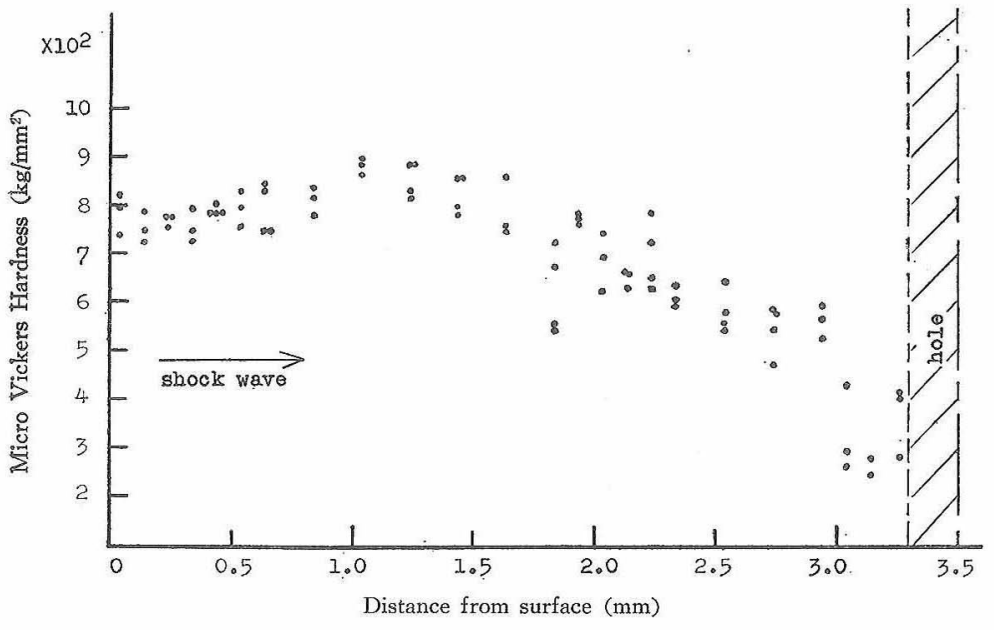

Fig. 15. Micro Vickers hardness distribution of explosively compacted $\mathrm{ZrO}_{2}$, using $83 \mathrm{~g}$ of Tetryl. $\left(\mathrm{ZrO}_{2}+\mathrm{HfO}_{2}=99.5 \%\right.$ in purity $)$

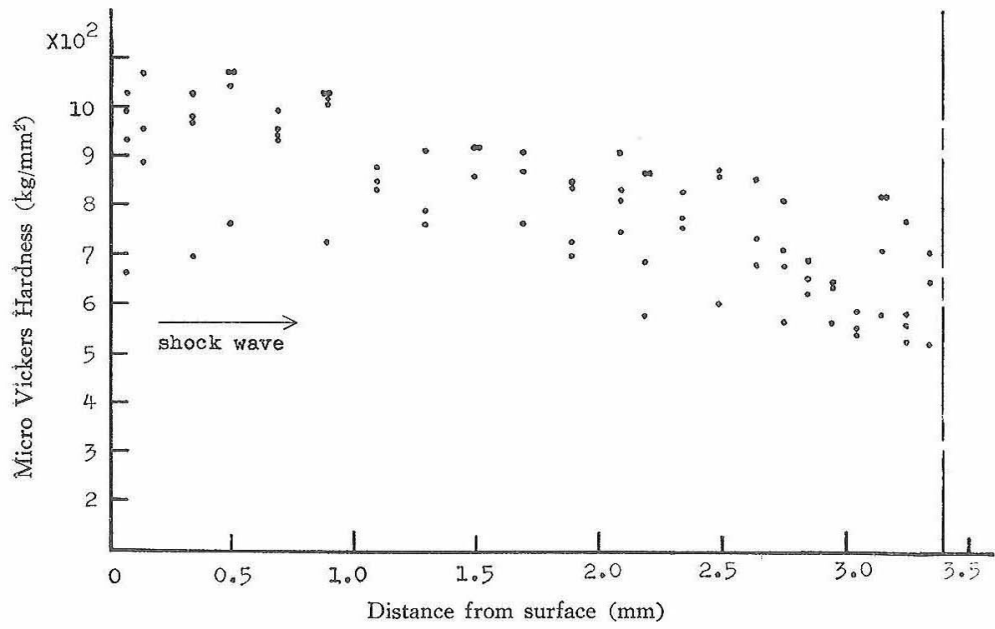

Fig. 16. Micro Vickers hardness distribution of explosively compacted $\mathrm{ZrO}_{2}$, using $105 \mathrm{~g}$ of Tetryl. $\left(\mathrm{ZrO}_{2}+\mathrm{HfO}_{2}=99.5 \%\right.$ in purity $)$
は外縁部である。

これらの硬度分布は純度 99.5 960 粗い粉末ジルコニアを用いて 得られた一連の圧搾体についての 結果であるが，テトリル使用量の 增加に応じて, 最大硬度はそれぞ れ $780,900,1070 \mathrm{~kg} / \mathrm{mm}^{2}$ であ ot.

ジルコニアの硬度に対する衝 撃波の影響索はっきりさせるため No. 8 で用いた純度 $99.9 \%$ ジル コニア粉末を原料とし，高周波炉 で加熱して嵩密度 $96.5 \%$ T.D., 気孔率 $1.6 \%$ の緻密な非安定化ジ ルコニア焼結体を作製した。

図-17 A 流 $10^{-4} \mathrm{mmHg}$ の真空 中， $2300^{\circ} \mathrm{C}$ で加熱して得られた 黑色の非化学量論的ジルコニア焼 結体，図-17 B はこれ空気中， $1000^{\circ} \mathrm{C}$ で空気酸化して得られる 白色で変態によるクラックのない 焼結保である ${ }^{22)}$.

この白色燒結体の微小硬度の平 均值は $540 \mathrm{~kg} / \mathrm{mm}^{2}$ であった。こ の値との比較から，衝撃波による 圧搾焼結体はかなりの加工硬化を 受けていることが推測される。

をたたびたび述べたように衝 摮漰の収れん効果から中心部ほど 加工硬化の程度が大きくなるべき でるるが，中心部はクラック尓る いは中心孔の発生のため硬度はむ
場合の中心孔の発生は主として爆轟压力の不足に起因す るものであると考えられる。

図-15 は，テトリル使用量 $83 \mathrm{~g}$ (No. 6) の場合の圧 控体の半径硬度分布である。硬度怡めゆるやかに増加 し，1.1 mm 付近で最大となり，次いで中心孔まで徐々 に低下している. 中心孔の半径は約 $0.2 \mathrm{~mm}$ であり各 測定位置における硬度のバラつきは小さい。最大值を示 す位置はかなり内部に移りその愊も広い。

図-16 は，No. 5 の，試料円筒部のテトリル量の最も 多、場合の圧搾体の半径方向の硬度分布である. 硬度は 始め高いが $0.6 \mathrm{~mm}$ ぐらいから低下し中心に達する。 各測定位置におけるバラつきはかなり認められるが，全 体的にはこれまでの試料の中で最も硬い。罒-5の組織 と対态させると外縁部は約 $1 \mathrm{~mm}$ まで，中間部は約 2.6 $\mathrm{mm}$ まで, 中心部は $2.6 \mathrm{~mm}$ 以上に相当し，硬度分布 むそれにつれて変化している。この図では最も硬い部分
しろ低下する傾向が溞い。

こころでこのよらな中心孔の発生する機構の十分な解 明は成されておらず本研究の課題のひとつでもあるのだ

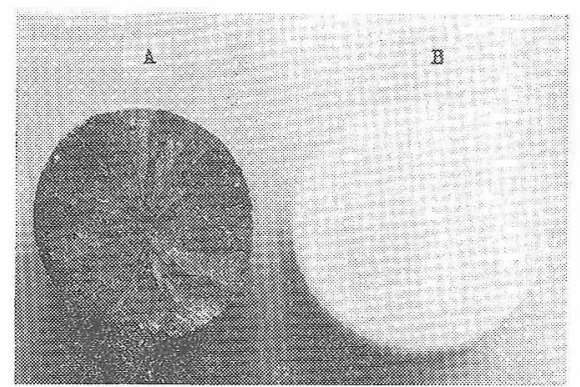

Fig. 17. Color change of pure sintered $\mathrm{ZrO}_{2}$ before (A) and after (B) oxidation in air at $1000^{\circ} \mathrm{C} .(\times 4.5)$

(A) : Oxygen-deficient $\mathrm{ZrO}_{2}$

(B) : Stoichiometric $\mathrm{ZrO}_{2}$ 
43 鈴木弘茂ほか

が, 従来, 主として伝播する衝撃波の中心部での膨脹波 一の変換と試料自体の弹性回復とに理由ゔけられてい $3^{2), 22)}$ ，爆薬量が多く衝擊波圧力が高すぎると压搾体の 中心に孔を生じ易いことが報告されているが，圧搾され る粉末の種類, 粒子の大きさなどによっては, 必ずしも 一義的ではない，テトリル量が少なすぎると衝撃波は伝 播中に減衰して中心部では圧力不足となり粒子間に十分 な結合をむたらすに至らず大きな中心孔を生ずる（図一 4). 粗い粒子からなるジルコニア原料粉末の場合, すな わち No. 4 7 では爆薬量の多いほど, 中心孔は小さく なって，その影響むまた小さくなる。

さらに中心孔の発生機構の解明を試みるために本実験 では予備的に装置内に法込亦れた軟鋼栓で中心孔の生 ビたものの微小硬度分布とその焼鈍挙動を調べ, あわせ て非衝撃栓の硬度およびその焼鈍変化も測定した（図一 18 (a)，(b)). 焼鈍条件 は真空中 $\left(10^{-3} \mathrm{mmHg}\right) 200^{\circ}$, $400^{\circ} \mathrm{C}$ で各 1 時間, $800^{\circ}, 1000^{\circ} \mathrm{C}$ で各 30 分間加熱し, その都度硬度を測定した。これまでの測定と同様に明石 製作所製微小硬度計を用い, 荷重 $100 \mathrm{~g}$ で行なった。

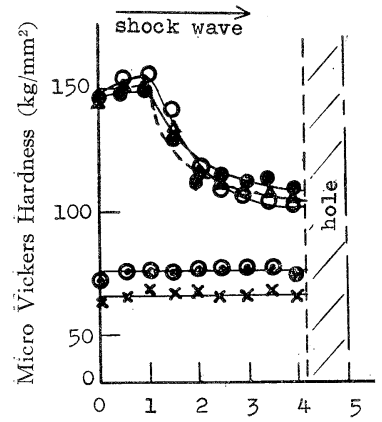

Distance from surface $(\mathrm{mm})$

(a)

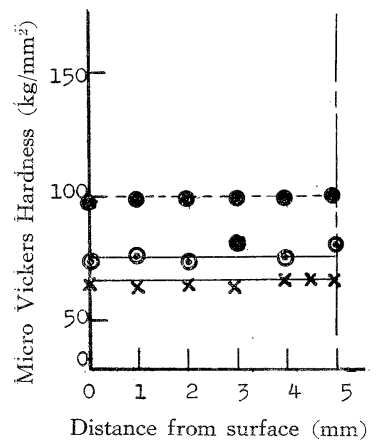

(b)

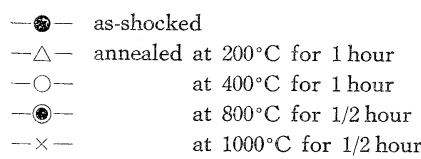

Fig. 18. Variation of micro Vickers hardness of steel plug during annealing. (a) explosively loaded specimen, (b) as-received specimen.

Calculated detonation shock pressure is about 120 kbar.
窯 業 協 会 誌 77 [8] 1969285

（a）では，衝撃試料の硬度は表面から $1 \mathrm{~mm}$ のとこ ろまで僅かに増加しているが, $1 \mathrm{~mm}$ から $2 \mathrm{~mm}$ にかけ て急激に低下し，さらに $4 \mathrm{~mm}$ のところまでゆるやか に減少して中心孔に達する。 $200^{\circ} \mathrm{C}, 400^{\circ} \mathrm{C}$ で㜔鈍後, 表面から $2 \mathrm{~mm}$ まで極く僅かな硬度増加が認められる が, $2.5 \mathrm{~mm}$ 以上では数パーセントの減少がみられる. この傾向は $400^{\circ} \mathrm{C}$ の焼鈍でも認められるが，一般的に は，これらの温度ではほとんじ燒鈍回復はない。 $800^{\circ} \mathrm{C}$ の焼鈍で急激な軟化を示し一倳分布となって半径方向の 著しい硬度の違いは消える。 $1000^{\circ} \mathrm{C}$ で硬度はさらに幾 分かの低下を示した。

衝撃波を受けてない軟鋼栓の場合 (b)，200，400 では全く硬度変化は認められず回復は起っていない。 $800^{\circ}, 1000^{\circ} \mathrm{C}$ の燒鈍で（a）の硬度にほぼ等しい值と なった。

（a，（b）の比較功軟鋼は衝撃波により冷間加工に 相当する加工硬化を受けていることは明らかである。し かし粉体の圧搾の場合のような衝撃波の伝播中の減衰 ${ }^{11}$ は小さく,むしろ収れんによって中心部ほど硬くなるは ずである. 従って（a）のような硬度分布や中心孔の発 生は, 単に衝撃波の機械的作用のみを考えては説明し難 W.

まず中心部は多量の加工を受けて ${ }^{23) ~ 25) ~}$ 劣化し, すで にジルコニア圧搾実験で確かめた膨脹波の作用が加わっ て孔を生ずることが考えられる，一方，炭化物合成実験 で確認したよらに, 衝撃波の瞬間的加熱による半径方向 の温度分布のため軟鋼は圧縮を受けた後に，一部の欠陥 を焼鈍回復する（a）に示したよらな硬度分布は，この ような劣化あるいは回復の結果生じたものと考えざるを 得ない。

なお，中心孔の発生機構のひとつとして上述のような 温度による熔融も考えられるが，鋼の大きな熱伝導性を 考えると中心部の到達温度はそれほど高くないであろ う。（a）と（b）加ら，その到達有効温度は $1000^{\circ} \mathrm{C}$ に注 達していないと見られる.しかし, 試料が熱伝導性の低 、物質である場合，たとえば炭化物合成のための炭素と 金属の混合粉末やジルコニア粉末では, その到達温度は かなり高く $1000^{\circ} \mathrm{C}$ あるいは $1300^{\circ} \mathrm{C}$ 以上に達している 可能性もある。衝撃波圧力の増大は，これらの温度を

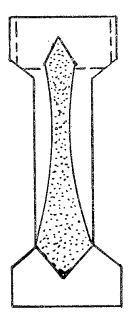

Fig. 19. High pressure and temperature region in steel tube (shadowed). 
もっと高めるであろう。このことは実験結果から推察さ れる。

以上の各種の物質についての硬度分布，組織写真およ び炭化物生成状況などを総合すると，本実験で使用した 装置内の圧力および温度分布は，大体図-19 の影を施し た部分のようになる。しかし, このような部分は, 爆薬 量と充填される試料の種類, 性状, 充填具合などによっ て、いくらか違ったものになるかもしれない。

\section{4. 総括}

衝撃波による極めて短時間の炭化反応，粉体の燒結の 現象を確認すると共に，これを発展させて装置の幾何学 的形状，位置による衝摮波の粉体におよぼす影響の違い を, 主として X線分析, 顕微鏡観察, 微小硬度測定に よって調べた。結果を総括すると

（1）衝撃波によって結晶粒子は巨視的にも微視的に も破壞を受けていわゆる活性状態になり，炭化反応や焼 結が極めて進行し易くなる。

（2）圧搾燒結体はかなり加工硬化を受けており，結 晶中に相当の残留歪のあることが推察される。

（3）衝撃波の圧力，温度の効果は装置内の位置に よってかなり差異があり，一般的には，試料円筒の中心 部分でそれが著しくなる。

（4）ジルコニア粉末の圧搾ではテトリル使用量の少 ないほど大きな中心孔主生じたが，このような圧搾体中 心の孔やクラックの発生原因は，従来説明されている膨 脹波への変換，試料自体のスプリング・バックのほか に，試料の脆化や劣化，衝撃波の隇衰効果が考えられ る。

（5）ジルコニアは，かなり粗い粉末でも緻密堅固な 焼結体となる。その組織中の粒子は，いずれも表層部あ るいは中心部さで，極めて微細化されており，これが焼 結の進行に大いに寄与していると考えられる.

以上から，衝撃波の有するエネルギーは金属炭化物の 合成法および高融点物質の焼結法として十分有効なもの であることがわかった、しかしながら，衝撃波の伝播の 様子と压力や温度に関するより詳しい知識，目的に応じ た爆薬の種類の量, 装置の形状の選択など多くの検討す
ベき問題も残っており，今後の研究に待つところがなお 大きいと言わざるを得ない。

\section{文献}

1) S.W. Porembka and C.C. Simons, ASTME paper SP 60-102 October, 1960.

2) S.J. Paprocki, C.C. Simons and R.J. Carlson, ASTME. paper SP 69-29 October, 1962.

3) S.W. Porembka Cerm. Age 79 [12] 69 (1963).

4）木村康之, 山本富才, 精密機械 3 [7] 617 (1965).

5) Japanese Patent, No. 1952, Patented Mar. 23 (1966).

6) Y. Horiguchi and Y. Nomura, J. Less-Common. Metals 11, 378 (1966), (short communications).

7) Melvin A. Cook, The Science of High Explosives, Reinhold Publishing Corp., New York (1961).

8) R. Caldirola, J. Chem. Phys. 14 [12] (1946).

9) R.L. Scorah, J. Chem. Phys. 3, July (1935).

10）㱜田 強, 科学 33 [12] 575 (1963).

11) H.T. Hall, F.P. Bundy and W.R. Hibbard, Jr. H.M. Strong Edit, Progress in Very High Research, John Wily \& Sons, Inc., (1961).

12) R.S. Bradley, High Pressure Physics and Chemistry, Vol. 2 Academic Press, London and New York (1963).

13）西山卯二郎, 井上 卓, 塑性と加工 8 [72] 10 (1967)。

14）西山卯二郎, 井上 卓, 日本機械学会諭文集 29 [208] 1889 (1963).

15）西山卯二郎, 井上 卓, 奥野正雄, 日本機械学会論文集: 30 [217] 1040 (1964).

16）西山卯二郎, 井上 卓, 奥野正雄, 日本機械学会論文集: 33 [250] 990 (1967).

17）橋口隆吉, 照射損傷, 界面現象, 格子欠樎 259-338, 共 立 (1958)。

18) L.T. Chadderton, Radiation Damage in Crystals, Methuen \& Co., Ltd. (1965).

19) Japanese Patent, No. 24961, Patented Nov. 1, 1965.

20）河嶋千尋，超高圧・超高温の物性と応用，金原（1968）.

21）倉谷健治, 土屋荘次, 衝擊波の化学物理, 裳華房 (1968).

22) H.J. Garrett and R. Robert, Am. Ceram. Soc. Bull. 47 [6] 578 (1968).

23) W.C. Leslie, E. Hornborgen and G.E. Dieter, J. Iron. Steel Inst. 200, 622 (1962).

24) B.A. Stein and C. Johnson, Trans. Met. Soc. AIME, 227, 1188 (1963).

25) R.O. Scattergood, P. Beardmore and M.B. Bever, Trans. Met. Soc. AIME, 227, 1486 (1963).

26) J.F. Kircher and R.E. Bowman, Effects of Radiation. on Materials and Components, Reinhold Publishing: Corp. (1964).

(2/12/1969 受付) 